the critical point in Biehl's analysis and hope for more exploration of the cultural role of myth. They will be disappointed. Biehl is clearly not interested in taking the poststructuralist route via Barthes, preferring instead to organize her criticism of ecofeminist theory from the lane marked 'social ecology'. Biehl uses Murray Bookchin's 'dialectical naturalism' as an alternative model for defining nature and argues that this theoretical concept allows for the possibility of what all eco-theorists appear to want - a different and less damaging relationship between humanity and the natural world.

Unfortunately, from the moment at which she names her preferred way of theorizing the world Biehl's work loses its critical edge. In reproducing Bookchin's arguments explanation comes perilously close to exultation. Dialectical naturalism, she explains, is an holistic approach which looks at the world as a whole from a developmental perspective. It is a theory of progress which posits a necessary passage from a state of 'potentiality' to that of full development which, in the case of individuals allows for the ultimate destination of self-actualization. One example given is the development of the individual from a state of childhood to a 'fuller more differentiated being'. What this example does not

\section{Getting Smart: Feminist Research and Pedagogy With/In the Postmodern}

\section{Patti Lather}

Routledge: New York/London 1991 ISBN $0415903777 £ 35.00 \mathrm{Hbk}$

Research on gender inequality in education and postmodernism has never really clicked. The emphasis on improvement and action in educational research and the orientation of research on the individual learning and development processes of teachers and pupils appear to be at address is the vast debate around the issue of just where the boundaries lie between childhood and adulthood and just what it means to be a fuller more differentiated being'.

In fact, the theory of dialectical naturalism seems little more than greenspeak for personal growth. There is an unnerving similarity between Biehl's enthusiastic espousal of Bookchin's theory and the work of ecofeminist writers. Both share a fervent belief in one key set of ideas and while it is often satisfying to be taken in an obvious direction by an author with a set destination in mind, there is a lot to be said for the theory flirt. An author who has not quite settled on a complete explanation for everything but who was willing to engage with a range of ideas may have produced a more satisfying critique of ecofeminist politics.

To be fair, Biehl's project is to rethink rather than just demolish ecofeminism and this she does. Her ultimate desire is clearly stated: to see the elimination of capitalism and the nation-state and the restructuring of society into decentralized, cooperative communities. For Biehl the problem with ecofeminists is not what they aim to do but the way that they do it.

\section{Shelagh Young}

odds with postmodernism. The line of argument inspired by postmodernism of 'gender as a social construction', which has proved fruitful in other areas of women's studies, has scarcely produced any research on gender and educational issues (ten Dam and Volman, 1991). The few exceptions concern smallscale research projects (e.g. Davies, 1989). Patti Lather's Getting Smart qua theme really gets to the heart of the matter. Lather tries to make a connexion between feminism, postmodernism and critical educational theory and considers the conse- 
quences of such a connexion for research and teaching. In our work we try to apply postmodern insights to research into education and gender inequality. Especially the criticisms that postmodernism precludes questions of improvement, and that it conceptually excludes agency of women and men, are bothering us. It is against this background that we have read Getting Smart.

Lather defines postmodernism as a discourse in which knowledge is continually seen in relation to power, in which the subject is no longer central and in which totalizing explanations are broken with. The relationship between feminism and postmodernism is one of love and hate. According to Lather, postmodern thinking in women's studies results in the paradoxical situation that, on the one hand, a 'feminine' subjectivity is increasingly sought which can liberalize the masculine concept of rationality while, on the other hand, the new, scarcely established 'feminine' identity is already being deconstructed. Lather concurs with others within women's studies who have pointed out the danger of political nominalism in the postmodern: does the subject's room for action not disappear with the (coherent) self, and does a welldefined category 'woman' or 'gender' not remove the possibility for political action? (Young-Bruehl, 1987; Tress, 1988; Alcoff, 1989) At the same time, there are attractive sides to postmodernism. According to Lather, it instructs feminists to bring dominant discourses up for discussion and to avoid dogmatism and reductionism themselves.

Lather does not only consider the question of the significance of postmodernism for feminism, she also turns the question upside down in her argument that feminism is the 'quantum physica' of postmodernism. First, it is within feminism that the relationship between theory and practice has been researched most creatively. Second, 'action' and 'sub- jectivity' are continually pointed out within the feminine discourse as essential elements for social change. Finally, feminism has a tradition of self-reflection, which Lather considers essential to prevent new discourses of truth. This all means that feminism is pre-eminently suitable for politicizing postmodernism. Following this introduction, the implications of this politicized postmodernism are explored for educational research and teaching.

In spite of the exciting questions raised in Getting Smart and the sympathetic approach, we were disappointed by the book from this point on. The next four chapters which are about research are full of repetition. Lather also takes the principle of intertexuality extremely literally; large parts of the book consist of citations strung together. The way in which the questions she raises are dealt with is also not very satisfactory.

The research advocated by Lather strongly resembles the action research of the seventies. According to the author, research must produce emancipatory knowledge that will enable the oppressed to understand and change their own reality (p. 53). Not only the research product is important but also the research process. In this process there must be an element of reciprocity between the researcher(s) and the researched, as well as an interchange between theory and empiricism. The research process must persuade the researched to reorientate themselves on their reality to such an extent that they are able to change ('catalytic validity'). The analysis of the researcher must go further than the experience of the researched without withholding subjectivity from them.

There are, however, a number of problems in connexion with the idea of reciprocity that are not discussed in the book. Are research results not valid, for example, when the researched do not subscribe to the interpretation of the researcher? 
That Lather emphasizes the socially constructed, historically embedded and value-related character of knowledge is new compared to action research. The result of research should not be a new, 'true' story. This raises certain questions for researchers, like: can I develop meanings when processing empirical data, instead of restricting them, how can I produce multi-voiced, multi-centred texts, and how can I deconstruct how my own longings as emancipatory researcher give form to the text?

The author answers these questions in the last chapter of Getting Smart by means of an example. In this chapter, Lather shows how she tries to put into practice in teaching and research the principles explained earlier. She presents the results here of research on the resistance of students in an introductory women's studies course. The research data was collected over a period of three years from interviews with students, research reports, extracts from those students' diaries and from notes made by the researcher herself. The central theme of the research is, in fact, the problem with which Lather sees herself confronted as a teacher: the conflict between the desire to instil certain perceptions into students and the fear of forcing these perceptions on them.

Lather has produced a 'multivoiced text' about her research. Instead of presenting her findings in one report, she tells four different stories about her data. The development undergone by Lather in recent years is evident in these stories: from a neo-Marxist, feminist researcher who questions, preferably by means of action research, why people resist or shut themselves off from 'good' perceptions of their own situation in life; to someone who is aware of the difficulties involved in understanding knowledge as the representation of reality, who is aware of the role of the researcher in the production of meaning and of the power attached to every categorization. She calls the first story 'realistic'. It assumes that by using an adequate research method it is possible to know the reality. The second story is the 'critical' story that in particular takes note of the underlying power structures. The third story is titled 'deconstructive'. It puts the unsaid and the unsayable in texts to the fore and explains its own constitution. The last account is the 'reflexive'. It brings the narrator back into the story with her desires and life history. Unfortunately it remains unclear what the relationship is between the four stories. Do they form a hierarchy? Are all four ultimately necessary? Lather of course does not end her book with an unequivocal position or conclusion. She closes with a postscript, an epilogue, an afterword and a coda which summarize what the book is about in four different ways.

Our disappointment is maybe particularly connected to the problems which are raised by weaving together three traditions of thinking - Marxism, feminism and postmodernism; problems which are sometimes pointed out by Lather, but scarcely made any clearer, let alone solved. She calls her argument first and foremost post-Marxism. It is 'Marxist' in the sense that the struggle for liberation is the central issue and 'post' because this is not, and cannot be, the only argument. In the second place, Lather sees her position as post-feminist. She calls for research that would correct the invisibility and distortion of women's experiences with a view to eliminating the unequal position of women (p. 71). The prefix 'post' serves again to avoid totalizing narratives. The 'post' element undoubtedly refers to the third tradition of thinking, the postmodern one. In several places it is doubtful how 'post' the approach proposed by Lather really is. The Marxist element does seem to be dominant given that Lather talks about oppression, liberation and emancipation, and she struggles 
with the concept of 'false awareness'. The 'experiences, desires and needs of women' are also regularly and heedlessly presented as unequivocal and recognizable factualities. In our opinion the interesting question of the possibilities and impossibilities of 'agency' and 'change' within a postmodern framework merit discussion in greater detail.

Getting Smart is above all a quest by Lather the academic and teacher through reams of literature about postmodernism, feminism and pedagogy for an explanation for her ambivalent attitude towards the postmodern. As a result of this quest the author, according to what she herself says, sees perspectives for 'those who want their intellectual involvement to be able to play a role in the struggle for social justice'. With her book, Lather has stressed yet again that it is important to think about this subject. She has not shown us perspectives for our actual work, in which we want to make use of the postmodern's intellectual power to attract in research that contributes to fairer education.

\section{Geert ten Dam and Monique Volman}

\section{References}

ALCOFF, L. (1989) 'Cultural feminism versus poststructuralism: the identity crisis in feminist theory', in MALSON, R., O'BARR, J., WESTPHAL-WIHL, $S$. and WYER, M., editors, Feminist Theory in Practice and Process. Chicago and London: University of Chicago Press: 295-326.

DAVIES, D. (1989) 'The discursive production of the male/female dualism in school settings' Oxford Review of Education 15: 229-42.

TEN DAM, G. T.M. and VOLMAN, M. L. L. (1991) 'Conceptualizing gender differences in educational research: the case of The Netherlands' British Journal of Sociology of Education 12: 309-21.

TRESS, D. (1988) 'Comments on Flax's "Postmodernism and gender relations in feminist theory"' Signs 14: 196-200.

YOUNG-BRUEHL, E. (1987) 'The education of women as philosophers' Signs 12: 207-21.

\section{'Race', Gender and the Education of Teachers} Edited by Iram Siraj-Blatchford

Open University Press: Buckingham 1993

ISBN $0335190170 £ 12.99 \mathrm{Pbk}$

With so much work published on issues of equality in education generally, it is surprising that this is the first collection to be devoted entirely to teacher education. The stated aim of the book is 'a very practical introduction to the specific issues of concern to teacher educators'. It is divided into three sections. The first section sets out to present a holistic view of 'race' and gender issues in teacher education considered in their wider educational context. The second section is chiefly concerned with the experiences of students and the final section examines policy, strategy and action required to promote equality in and through teacher education. The book is aimed at teacher educators and students and serves as a good introduction for those coming to the issues for the first time. It is also a useful text in presenting the current debate in a context where teacher education is being politically structured to take place largely in and under the control of schools.

The changes occurring in teacher education parallel those taking place in the school sector. The removal of powers from teacher education institutions themselves and their delegation to schools combined with increased central government direction over the nature and content of courses follows the delegation of school policy from local authorities to school governing bodies and the introduction of the National Curriculum. These political changes are consciously intended to eliminate the promotion of equality under an ideology of choice and standards. In this context the pursuit of equality in 